\title{
OPTIMASI PENEMPATAN KAPASITOR BANK UNTUK PERBAIKAN RUGI DAYA PADA PENYULANG SABA MENGGUNAKAN ALGORITMA GENETIKA
}

\author{
I. K. A. Wijaya*, R. S. Hartati, I W. Sukerayasa \\ Program Studi Teknik Elektro, Fakultas Teknik, Universitas Udayana \\ Email : ariwijaya058@gmail.com*
}

\begin{abstract}
ABSTRAK
Penyulang Saba merupakan penyulang yang menyuplai 78 trafo distribusi dengan panjang penyulang 38,959 kms, melalui penyulang Saba ini energi listrik disalurkan secara radial ke masing-masing gardu distribusi. Pada tahun 2017 susut tegangan pada penyulang Saba sebesar 9,88 \%(18,024 kV) sedangkan total rugi daya sebesar 445,5 kW. Pada penelitian ini dilakukan usaha untuk mengatasi susut tegangan dan rugi daya dengan metode optimasi penempatan kapasitor bank dengan algoritma genetika dan rekonfigurasi jaringan. Solusi terbaik yang diperoleh dari penelitian ini akan dipilih untuk perbaikan susut tegangan dan rugi daya pada penyulang Saba. Hasil penelitian menunjukan bahwa dengan melakukan optimasi kapasitor bank menggunakan algoritma genetika diperoleh penempatan kapasitor bank pada bus 23 (saluran menuju trafo BB0024) dan berhasil menurunkan rugi daya menjadi 331,7 kW. Rekonfigurasi jaringan berhasil memperbaiki tegangan pada penyulang Saba dengan drop tegangan sebesar 4,75 \% dan total rugi dayanya sebesar 182,7 kW. Dengan metode gabungan rekonfigurasi dan optimasi kapasitor bank dengan algoritma genetika diperoleh penempatan pada bus 27 (saluran menuju trafo BB0047) dan berhasil menurunkan rugi daya mencapai $143 \mathrm{~kW}$.
\end{abstract}

Kata Kunci : Drop Tegangan, Load Flow Analysis, algoritma genetika

\section{ABSTRACT}

Saba feeder is a feeder who supplies 78 distribution transformers with feeder length $38,959 \mathrm{kms}$, through this Saba feeder electrical energy is channeled radially to each distribution substation. In 2017 the voltage shrinkage at Saba feeder was 9.88\% (18,024 kV) while the total power loss was $445.5 \mathrm{~kW}$. In this study an attempt was made to overcome the voltage losses and power losses using the method of optimizing bank capacitors with genetic algorithms and network reconfiguration. The best solution obtained from this study will be selected for repair of voltage losses and power losses in Saba feeders. The results showed that by optimizing bank capacitors using genetic algorithms, the placement of capacitor banks was placed on bus 23 (the channel leading to the BB0024 transformer) and successfully reduced the power loss to $331.7 \mathrm{~kW}$. The network reconfiguration succeeded in fixing the voltage on the Saba feeder with a voltage drop of $4.75 \%$ and a total power loss of $182.7 \mathrm{~kW}$. With the combined method, reconfiguration and optimization of bank capacitors with genetic algorithms were obtained on bus 27 (channel to transformer BB0047) and managed to reduce power losses to $143 \mathrm{~kW}$.

Keywords : Drop Voltage, Load Flow Analysis, Genetic Algorithms

\section{PENDAHULUAN}

Data yang didapat dari PT Perusahaan Listrik Negara (PLN) Area Bali timur diperoleh bahwa pada tahun 2017 susut tegangan pada Penyulang Saba sebesar 9,88 \% $(18,024 \mathrm{kV})$ sedangkan total rugi daya sebesar 445,5 kW dan perkiraan susut tegangan pada tahun 2020 akan melebihi 10\%[1] . Merujuk pada SPLN No.72 tahun 1987[2] yaitu jatuh tegangan yang diperbolehkan pada jaringan tegangan menengah dan jaringan tegangan rendah adalah $2 \%$ dari tegangan kerja untuk sistem spindle dan $5 \%$ dari tegangan kerja yaitu untuk sistem radial. Sehingga susut tegangan di Penyulang Saba sudah menjadi perhatian khusus karena angka susut sudah melewati batas susut yang diizinkan maka dari itu perlu dilakukan perbaikan untuk meminimalkan nilai susut tegangan dan rugi daya. Sehingga dapat dilihat jika nilai tegangan diatas 
batas standar maka akan berpengaruh baik pada penggunaan peralatan listrik yang digunakan oleh konsumen. Sedangkan rugi-rugi daya yang kecil akan menjaga pasokan daya listrik sesuai dengan kebutuhan konsumen, serta dapat mengurangi kerugian finansial yang terjadi selama proses transmisi dan distribusi.

Pada penelitian ini dianalisis rugi daya pada Penyulang Saba menggunakan studi optimasi penempatan kapasitor bank dengan algoritma genetika serta metode rekonfigurasi jaringan dalam upaya memperbaiki kestabilan tegangan serta faktor daya sehingga dapat menentukan metode mana yang tepat dilakukan untuk perbaikan rugi daya di Penyulang Saba.

\section{KAJIAN PUSTAKA}

Teori-teori penunjang yang digunakan pada penelitian ini adalah sebagai berikut :

\subsection{Jaringan Distribusi Tenaga Listrik}

Sistem distribusi tenaga listrik memiliki dua fungsi utama, yaitu sebagai pembagi energi listrik, dan juga sebagai sub sistem dari tenaga listrik itu sendiri. Tenaga listrik dihasilkan oleh sebuah pembangkit listrik.Tegangan yang dihasilkan oleh pembangkit tersebut kemudian dinaikkan oleh gardu induk menggunakan transformator step up sehingga menjadi 70 kilo volt, 154 kilo volt, 220 kilo volt, atau 500 kilo volt yang kemudian dialirkan menuju ke saluran transmisi. Selanjutnya dari saluran transmisi, tegangan diturunkan menjadi 20 kilo volt menggunakan trafo step down yang berada pada gardu induk distribusi. Dengan menggunakan sistem tegangan tersebut tenaga listrik disalurkan oleh saluran distribusi primer. Setelah itu tegangan diturunkan menjadi $220 / 380$ volt oleh trafo yang berada pada gardu distribusi. Terakhir saluran distribusi sekunder akan menyalurkan listrik kepada konsumen-konsumen [3].

\subsection{Kapasitor Bank}

Bank kapasitor (capacitor banks) adalah peralatan yang digunakan untuk memperbaiki kualitas pasokan energi listrik antara lain memperbaiki mutu tegangan di sisi beban, memperbaiki faktor daya (cos phi) dan mengurangi rugi-rugi transmisi. Kapasitor Bank terdiri dari beberapa kapasitor yang dihubungkan secara parallel/seri untuk mendapatkan kapasitas kapasitif tertentu. Besaran parameter yang dipakai adalah KVAR (Kilovolt ampere reaktif) meskipun pada kapasitor sendiri tercantum besaran kapasitansi yaitu Farad atau microfarad [4].

\subsection{Algoritma Genetika}

Algoritma genetika sebagai cabang dari algoritma evolusi merupakan metode yang digunakan untuk memecahkan suatu pencarian nilai dalam permasalahan-permasalahan optimasi non-linier. Algoritma genetika direpresentasikan oleh urutan langkahlangkah prosedur kromosom buatan yang bergerak dari satu populasi ke populasi baru menggunakan seleksi alami dan teknik yang diambil dari genetika yang dikenal sebagai crossover dan mutasi. Setiap kromosom terdiri dari sejumlah 'gen', dan setiap gen diwakili oleh 0 atau 1 [5].

\section{Metodelogi Penelitian}

\subsection{Tahapan Penelitian}

Pertama dilakukan perhitungan segi teknis yaitu rugi daya pada penyulang Saba dengan metode rekonfigurasi jaringan dan optimasi penempatan kapasitor bank dengan metode algoritma genetika. Kemudian tahapan terakhir dari penelitian ini yaitu membandingkan antara metode rekonfigurasi jaringan dengan pemasangan kapasitor bank tersebut dari segi teknis yaitu penurunan rugi daya yang maksimal.

\subsubsection{Rekonfigurasi Jaringan}

Rekonfigurasi jaringan adalah pemotongan jaringan dengan melakukan pemindahan beberapa beban ke penyulang terdekat yang dimana penyulang terdekat tersebut 
masih memiliki beban yang kecil. Dapat dilihat dari penelitian ini, penyulang yang paling dekat dengan penyulang Saba adalah penyulang Mas dan penyulang Wibrata. Dilihat dari konfigurasinya penyulang Mas menyuplai 49 trafo distribusi dengan panjang penyulang 25,721 kms dan memiliki beban puncak sebesar 100 A sedangkan penyulang Wibrata menyuplai 33 trafo distribusi dengan panjang penyulang $13,353 \mathrm{kms}$ dan memiliki beban puncak sebesar 56 $A[1]$. Sehingga pada penelitian ini penyulang Wibrata yang akan diberikan sebagian beban dari penyulang Saba karena beban pada penyulang Wibrata masih kecil .

\subsubsection{Optimasi Kapasitor Bank Dengan Algoritma Genetika}

Untuk optimasi penempatan

kapasitor bank pada penyulang Saba menggunakan metode algoritma genetika dimana agar dapat menentukan dimana letak lokasi penempatan kapasitor bank yang paling efektif. Simulasi ini dirancang dengan beberapa tahap yaitu tahap pertama menentukan populasi awal, tahap kedua evaluasi seluruh individu untuk mencari individu dengan nilai fitness tertinggi, tahap ketiga menyeleksi populasi baru dari populasi awal lalu melakukan pindah silang selanjutnya dimutasi untuk menggantikan nilai gen yang hilang dari suatu populasi akibat seleksi yang memungkinkan munculnya kembali gen yang tidak dimunculkan pada saat proses inisialisasi populasi dan tahap terakhirnya didapatkan nilai fitness terbaik yang merupakan output dari metode algoritma genetika.

\subsection{Alur Analisis Penelitian}

Berikut pada Gambar 1 menunjukan diagram alur analisis penelitian yang merupakan langkah-langkah untuk memperbaiki rugi daya pada penyulang Saba. 


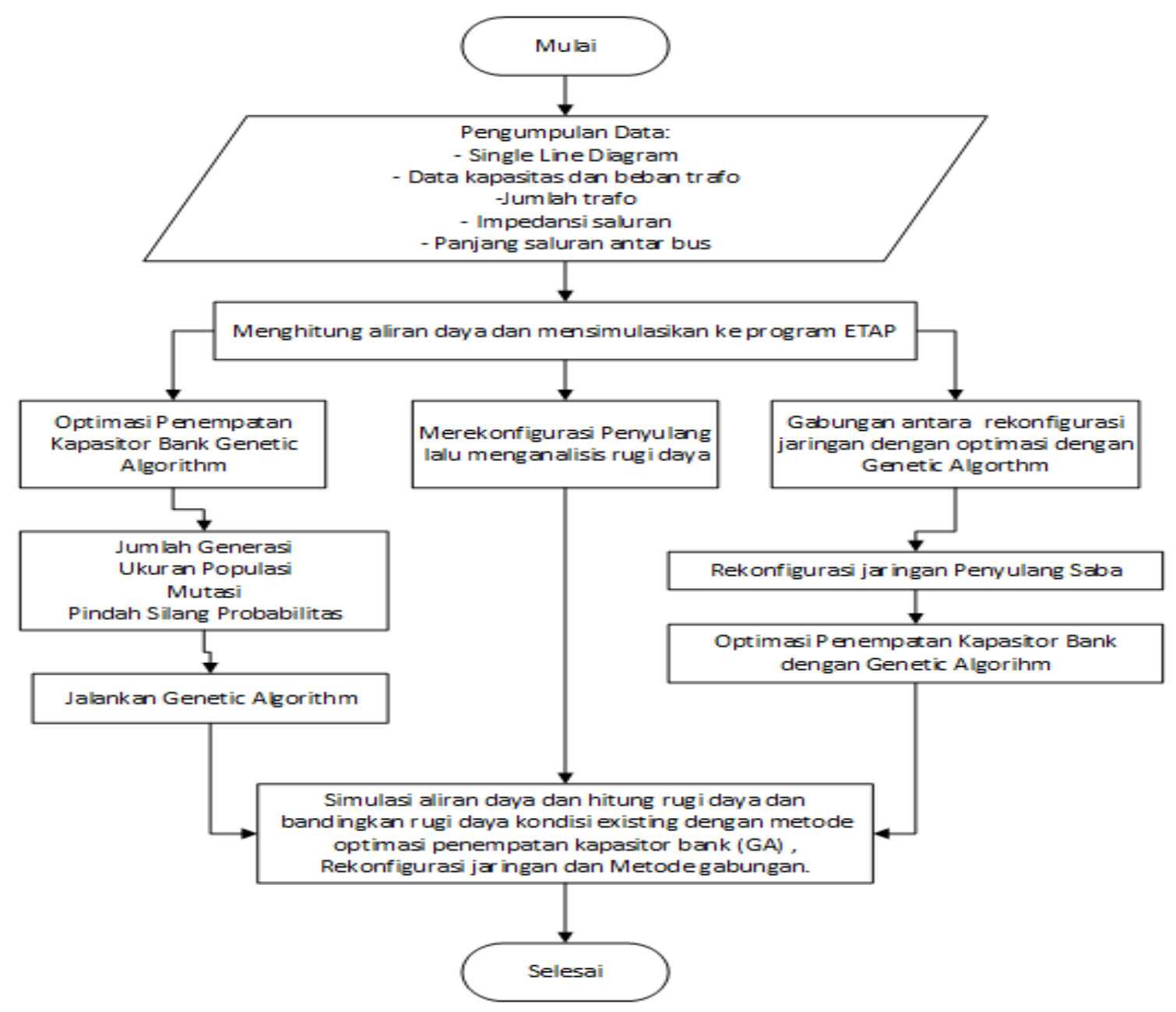

Gambar 1. Diagram Alur Analisis Penelitian

\section{HASIL DAN PEMBAHASAN}

Hasil dan pembahasan dari penelitian ini adalah sebagai berikut:

\subsection{Analisa Aliran Daya Penyulang} Saba Pada Kondisi Existing

Hasil analisis kondisi existing yang dilakukan, diperoleh pada Tabel 1 menunjukan 54 bus atau 17,3\% bus dari total sebanyak 282 bus mengalami drop tegangan yang melewati batas standar 10\%. Sehingga diperoleh tegangan terendah yaitu pada bus 246 dengan drop tegangan sebesar 13,18\% $(17,364 \mathrm{kV})$ dar sumber bus.

Tabel 1. Bus yang drop teganganya dibawah batas standar

\begin{tabular}{|c|c|c|c|}
\hline No & BUS & Drop (\%) & Tegangan (kV) \\
\hline 1 & 3_1 & 11,27 & 17,746 \\
\hline 2 & 4 & 10,16 & 17,968 \\
\hline 3 & 5 & 10,7 & 17,86 \\
\hline 4 & 6 & 11,24 & 17,752 \\
\hline 5 & $8 \_1$ & 12,27 & 17,546 \\
\hline 6 & 9_1 & 10,53 & 17,894 \\
\hline
\end{tabular}

\begin{tabular}{|c|c|c|c|}
\hline No & BUS & Drop (\%) & Tegangan (kV) \\
\hline 7 & $11 \_1$ & 10,23 & 17,954 \\
\hline 8 & $11 \_3$ & 10,26 & 17,948 \\
\hline 9 & $12 \_1$ & 11,88 & 17,624 \\
\hline 10 & 13 & 11,97 & 17,606 \\
\hline 11 & $13 \_2$ & 12,27 & 17,546 \\
\hline 12 & $16 \_1$ & 10,57 & 17,886 \\
\hline 13 & $17 \_1$ & 12,81 & 17,438 \\
\hline 14 & $20 \_1$ & 11,31 & 17,738 \\
\hline 15 & $22 \_2$ & 11,29 & 17,742 \\
\hline 16 & $22 \_1$ & 11,02 & 17,796 \\
\hline 17 & $23 \_1$ & 10,23 & 17,954 \\
\hline 18 & $25 \_1$ & 11,05 & 17,79 \\
\hline 19 & 29 & 11,15 & 17,77 \\
\hline 20 & 33 & 11,394 & 17,7212 \\
\hline 21 & 36 & 11,24 & 17,752 \\
\hline 22 & 37 & 11,24 & 17,752 \\
\hline 23 & 38 & 11,94 & 17,612 \\
\hline 24 & $38 \_1$ & 12,1 & 17,58 \\
\hline 25 & $43 \_1$ & 12,25 & 17,55 \\
\hline 26 & $43 \_3$ & 12,89 & 17,422 \\
\hline 27 & $50 \_1$ & 10,99 & 17,802 \\
\hline 28 & $52 \_1$ & 12,14 & 17,572 \\
\hline 29 & 56 & 12,05 & 17,59 \\
\hline
\end{tabular}




\begin{tabular}{|c|c|c|c|}
\hline No & BUS & Drop (\%) & Tegangan (kV) \\
\hline 30 & 58 & 11,21 & 17,758 \\
\hline 31 & 69 & 10,7 & 17,86 \\
\hline 32 & 98 & 10,05 & 17,99 \\
\hline 33 & 108 & 10,89 & 17,822 \\
\hline 34 & 163 & 10,978 & 17,8044 \\
\hline 35 & 185 & 10,89 & 17,822 \\
\hline 36 & 199 & 11,24 & 17,752 \\
\hline 37 & 203 & 10,48 & 17,904 \\
\hline 38 & 206 & 10,15 & 17,97 \\
\hline 39 & 246 & 13,18 & 17,364 \\
\hline 40 & 251 & 13,13 & 17,374 \\
\hline 41 & 254 & 13,13 & 17,374 \\
\hline 42 & 255 & 11,3 & 17,74 \\
\hline 43 & 257 & 11,29 & 17,742 \\
\hline 44 & 260 & 12,18 & 17,564 \\
\hline 45 & 261 & 11,32 & 17,736 \\
\hline 46 & 266 & 11,31 & 17,738 \\
\hline 47 & 269 & 11,95 & 17,61 \\
\hline 48 & 270 & 11,31 & 17,738 \\
\hline 49 & 273 & 11,27 & 17,746 \\
\hline 50 & 274 & 10,94 & 17,812 \\
\hline 51 & 277 & 12,76 & 17,448 \\
\hline 52 & 278 & 11,26 & 17,748 \\
\hline 53 & 279 & 12,16 & 17,568 \\
\hline 54 & 281 & 11,25 & 17,75 \\
\hline & & & \\
\hline
\end{tabular}

\subsection{Optimasi Penempatan kapasitor bank Dengan Algoritma Genetika}

Hasil analisis aliran daya menggunakan load flow akan digunakan sebagai data input untuk menentukan lokasi penempatan kapasitor bank dengan menggunakan metode algoritma genetika. Sebelum itu dilakukan perhitungan penentuan rating kapasitor bank.

\subsubsection{Penentuan Rating Kapasitor Bank}

Sebelum melakukan running program optimasi penempatan kapasitor bank dengan algoritma genetika, dilakukan perhitungan kebutuhan kapasitas kapasitor bank yang akan digunakan pada penyulang Saba dengan rumus sebagai berikut.

$$
\mathrm{Qc}=\mathrm{Q} 1-\mathrm{Q} 2 \text {. }
$$

Dimana : Qc = Daya reaktif kapasitor bank yang dibutuhkan

$\mathrm{Q} 1$ = Daya reaktif sebelum perbaikan

Q2 = Daya reaktif yang ingin dicapai

\subsubsection{Running Program}

Berdasarkan metode algoritma genetika penempatan kapasitor bank menunjukkan respon pengurangan rugi - rugi daya dengan penempatan kapasitor pada bus 23 (saluran menuju trafo BB0024). Gambar 2 menunjukan dilakukan 20 iterasi untuk mencari nilai losses terbaik sehingga didapatkan dengan nilai awal PLoss sebesar 500,9 $\mathrm{kW}$, penempatan 4 kapasitor bank pada bus 23 mampu menurunkan rugi-rugi daya menjadi $331,7 \mathrm{~kW}$ sehingga terjadi penurunan rugi daya sebesar 169,2 kW (6,6 \%). Seperti yang dijelaskan pada teori bahwa ketika ditambahkannya kapasitor shunt pada sistem jaringan, terjadi injeksi arus kapasitif (IC) sehingga faktor daya meningkat dan arus beban (IL) berkurang. Hal ini mengakibatkan drop tegangan berkurang sehingga tegangan terima ( $\mathrm{Vr}$ ) pada masing -masing bus mengalami peningkatan.

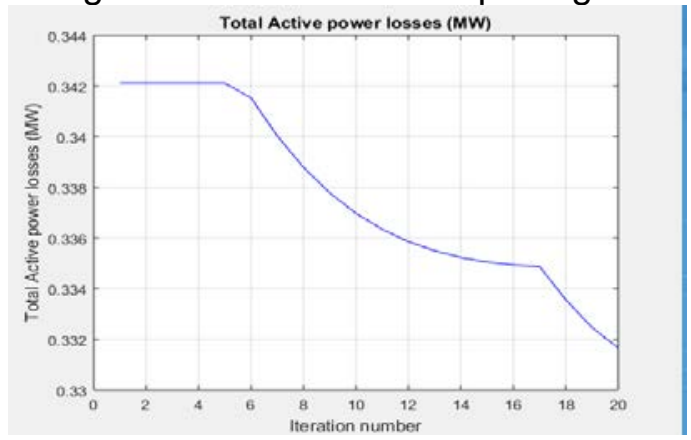

Gambar 2. Simulasi Program Optimasi

\subsection{Analisis aliran daya penyulang Wibrata}

Analisis aliran daya pada program ETAP didapat presentasi tegangan terendah pada bus sebesar $100 \%$ serta total rugi daya sebesar $28,2 \mathrm{~kW}$, hal ini terjadi diakibatkan karena pertumbuhan beban pada penyulang Wibrata masih rendah. Sehingga penyulang Wibrata memenuhi syarat untuk menerima pemindahan beban dari penyulang Saba.

\subsection{Rekonfigurasi Penyulang Saba}

Rekonfigurasi penyulang Saba dilakukan dengan pemotongan jaringan SUTM pada titik percabangan penyulang Saba yaitu pada LBS Manikan yang bertujuan untuk mengalihkan sebagaian beban 
penyulang Saba ke penyulang Wibrata. Pemilihan penyulang Wibrata dilakukan karena penyulang Wibrata merupakan penyulang yang paling dekat dengan penyulang Saba serta beban yang pada penyulang Wibrata masih cukup kecil dan dipastikan dapat menampung sebagian beban dari penyulang Saba. Beban penyulang Saba yang akan dipindahkan ke penyulang Wibrata sebesar 2,339 MW perhitungan dari beban LBS Manikan - LBS Batuyang dengan menambahkan jaringan dari LBS Manikan menuju LBS Lorin dengan panjang jaringan sebesar 8,19 $\mathrm{Km}$. Untuk lebih jelasnya dapat dilihat pada Gambar 3.

\subsection{Analisis Aliran Daya Penyulang Saba Setelah Direkonfigurasi}

s Analisis aliran daya pada program ETAP diperoleh tegangan terendah pada penyulang Saba setelah direkonfigurasi dengan pemotongan jaringan sebesar 95,141 \% sehingga tegangan yang dialirkan sebesar 19,028 kV pada bus 56 yang artinya presentase jatuh tegangan sebesar $4,85 \%$ pada penyulang Saba setelah direkonfigurasi, hal ini diakibatkan karena sebagian beban dari penyulang Saba sudah dipindahkan ke penyulang Wibrata.

Kemudian untuk total rugi daya penyulang Saba setelah direkonfigurasi sebesar 182,7 kW atau sebesar 4,75\% yang sebelumnya total rugi dayanya sebesar 500,9 kW. Dari hasil tersebut dapat dilihat penurunan rugi-rugi daya dari penghantar yang memiliki rugi daya yang paling besar di penyulang Saba disebabkan karena sebagian beban dari penyulang Saba sudah dipindahkan ke penyulang Wibrata otomatis jaringan pada penyulang Saba berkurang sehingga menyebabkan rugi daya menurun.

\subsection{Analisis Penyulang Wibrata}

Analisis aliran daya penyulang Wibrata diperoleh tegangan terendah pada penyulang Wibrata setelah ditambahkan beban dari penyulang Saba sebesar 97,63 \%, sehingga tegangan yang dialirkan sebesar 19,526 kV pada bus 95 hal ini diakibatkan dari penambahan beban dari penyulang Saba ke penyulang Wibrata sehingga penyulang Wibrata mengalami kenaikan rugi daya dan drop tegangan yang sedikit karena penyulang Wibrata awalnya memiliki beban yang kecil sebesar 56 A [1]. Kemudian untuk total rugi-rugi daya pada penyulang Wibrata setelah ditambahkan beban sebesar $145.8 \mathrm{~kW}$ sekitar 3,1 \%. 


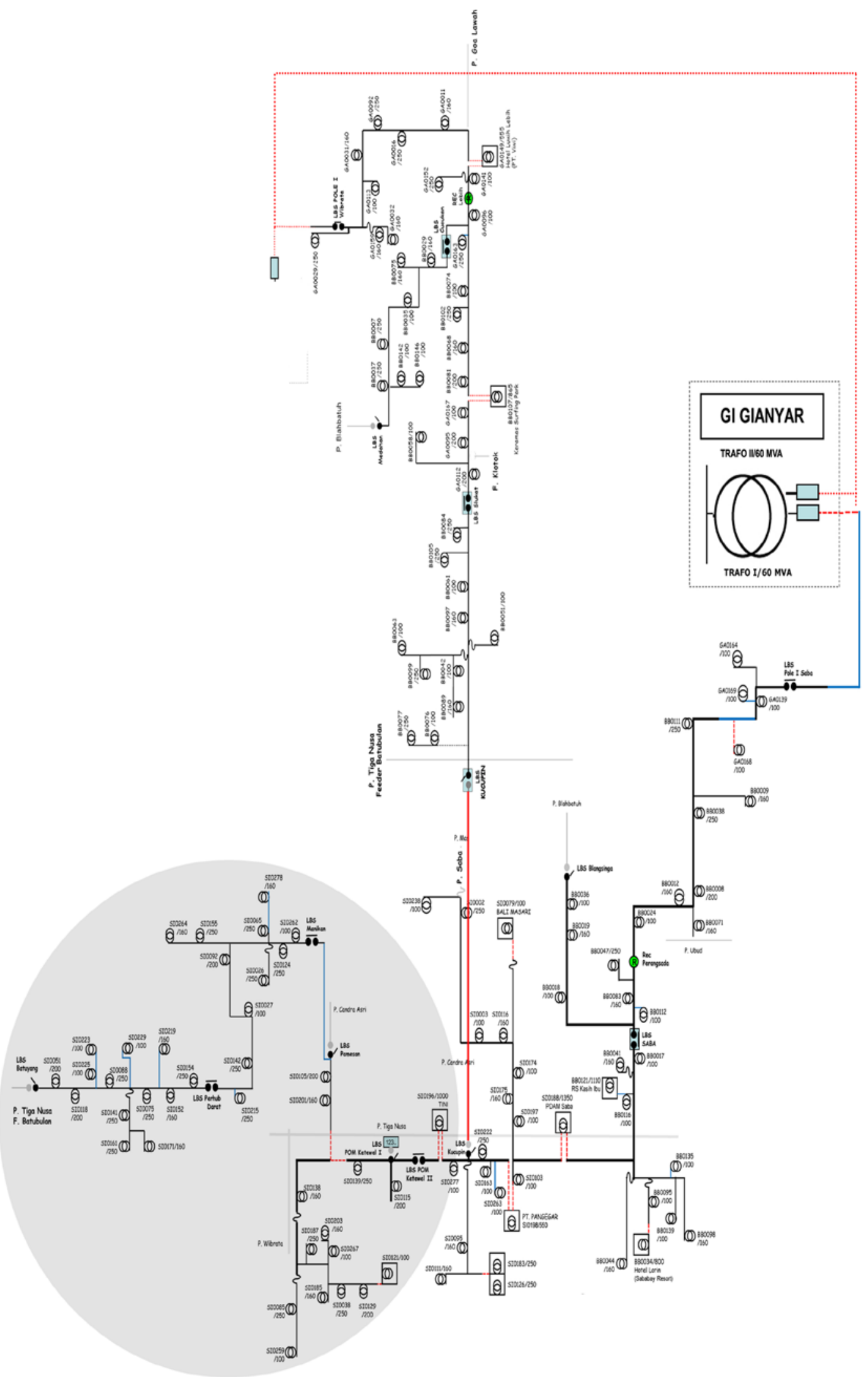

Gambar 3. Rekonfigurasi Jaringan Penyulang Saba 


\subsection{Optimasi Penempatan Kapasitor Bank dengan Algoritma Genetika Setelah Direkonfigurasi}

Berikut dilakukan metode gabungan antara metode optimasi penempatan kapasitor bank algoritma genetika dengan rekonfigurasi jaringan. Gambar 4 menunjukan dimana dilakukan sebanyak 20 iterasi untuk mencari nilai fitness terbaik hasil optimasi penempatan kapasitor bank menunjukkan respon pengurangan rugi - rugi daya dengan penempatan kapasitor pada bus 27 (saluran menuju trafo BB0047) dengan nilai awal PLoss sebesar 500,9 kW, penempatan 4 kapasitor bank pada bus 27 mampu menurunkan rugi-rugi daya menjadi 143 kW sehingga terjadi penurunan rugi daya sebesar 39,7 kW (6,6 \%). Seperti yang dijelaskan pada teori bahwa ketika ditambahkannya kapasitor shunt pada sistem jaringan, terjadi injeksi arus kapasitif (IC) sehingga faktor daya meningkat dan arus beban (IL) berkurang. Hal ini mengakibatkan drop tegangan berkurang sehingga tegangan terima $(\mathrm{Vr})$ pada masing - masing bus mengalami peningkatan.

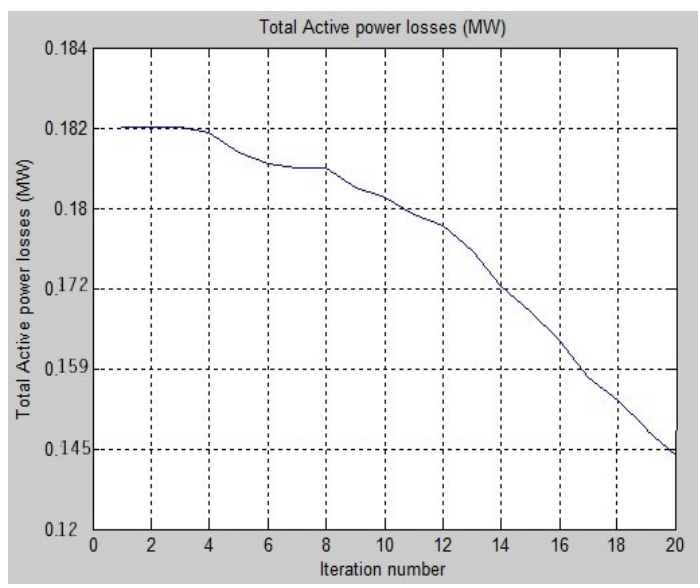

Gambar 4. Simulasi Optimasi Algoritma Genetika

\subsection{Analisis Perbandingan Aliran Daya Penyulang Saba Antara Sebelum Dengan Setelah dilakukan Rekonfigurasi dan Penambahan Kapasitor Bank}

Tabel 2. Hasil analisis perbandingan aliran daya Penyulang Saba sebelum dan sesudah direkonfigurasi dan di optimasi penempatan kapasitor

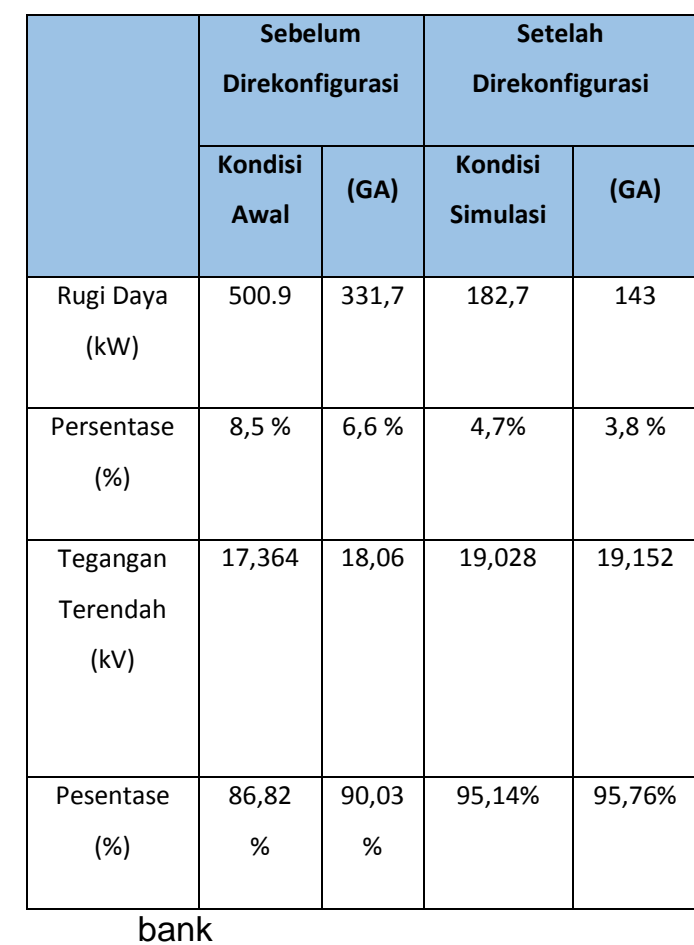

Berdasarkan Tabel 2 menunjukan adanya perbedaan total rugi daya dan tegangan pada sistem penyulang Saba. Penyulang Saba yang kondisi awalnya memiliki rugi daya $500.9 \mathrm{~kW}$ dan tegangan $86,82 \%$ setelah dioptimasi penempatan kapasitor bank dengan algoritma genetika sedangkan setelah penyulang Saba direkonfigurasi dengan memindahkan sebagian beban ke penyulang Wibrata, rugi daya dan tegangan penyulang Saba mengalami penurunan rugi daya sebesar 4,7\% atau 182,7 kW dan tegangan terendahnya menjadi 95,141 \% lalu setelah direkonfigurasi dilakukan juga penempatan kapasitor bank menggunakan algorima genetika dihasilkan lokasi penempatan kapasitor pada bus 27 (saluran menuju trafo BB0047), dengan menghasilkan penurunan rugi daya sebesar $143 \mathrm{~kW}$ (3,8 \%) dengan tegangan terendahnya sebesar 95,76 \%. Dari hasil 
perbandingan tersebut metode gabungan optimasi penempatan kapasitor bank dengan algoritma genetika serta rekonfigurasi jaringan lebih unggul dari segi teknis dalam hal memperbaiki rugi daya dan drop tegangan dibandingkan dengan metode lainnya yang digunakan untuk mengatasi permasalahan rugi daya dan drop tegangan pada penyulang Saba.

\section{KESIMPULAN}

Dari tiga metode yang digunakan yaitu optimasi penempatan kapasitor bank dengan algoritma genetika, rekonfigurasi jaringan, dan metode gabungan (optimasi kapasitor bank dengan rekonfigurasi jaringan) diperoleh metode gabungan lebih cocok digunakan untuk perbaikan rugi daya pada penyulang Saba karena menghasilkan total rugi daya sebesar $143 \mathrm{~kW}(3,8 \%)$ dengan penempatan kapasitor bank pada bus 27

\section{DAFTAR PUSTAKA}

[1] PT PLN (Persero). Rencana Usaha Penyediaan Tenaga Listrik 20152024. PLN, Jakarta, 2014g

[2] SPLN $72: 1987$, Spesifikasi desain untuk Jaringan Tegangan Menengah (JTM) dan Jaringan Tegangan Rendah (JTR), PLN 1987.

[3] Hermandos,Roni.2010. Perhitungan Susut Tegangan Sistem Distribusi 20 kVA Pada Penyulang Panalaran. Jurnal Universitas. Jurnal Universitas Maritim Raja Ali Haji.

[4] Noor ,Syamsudin .2014 . Efisiensi Pemakaian Daya Listrik Menggunakan Kapasitor Bank. Jurnal Politeknik Negeri Banjarmasin.

[5] Negnevitsky, M., 2005, Artificial Intelligence : A Guide to Intelligent Systems, 2nd edition, Pearson Education Ltd, Harlow, Englan

[6] Wimar,Chandra .2017. Optimasi Pemasangan dan Kapasitas
Kapasitor Shunt Pada Jaringan Distribusi Penyulang Menjangan .Jurnal Universitas Udayana.

[7] Ardiansyah, A. 2010. Jaringan Distribusi Tenaga Listrik. Medan :Universitas Sumatera Utara.

[8] Stevenson, Wiliam D. 1994. Analisis Sistem Tenaga Listrik. Jakarta : Erlangga.

[9] Toyota. 1995,.new step 2 Chasis group. Jakarta: PT. Toyota Astra Motor.

[10] Sulasno ,2001. Distribusi Tenaga Listrik .Semarang : Badan Penerbit Universitas Diponogoro.

[11] Kadir, Abdul. 2000. Distribusi dan Utilisasi Tenaga Listrik. Jakarta: Universitas Indonesia Press. 